UDC: $25(497)$

Владимир Д. Михајловић

Универзитет у Новом Саду

Филозофски факултет

Одсек за историју

v.mihajlovicc@gmail.com
Оригиналан научни рад

примљено: 20. март 2013

прихваћено: 1. октобар 2013

\title{
НАПОМЕНЕ О КУЛТУ ЈУПИТЕРА ДОЛИХЕНА НА ЦЕНТРАЛНОМ БАЛКАНУ*
}

Сажетак: Рад се осврће на неколико питања о култу Јупитера Долихена на подручју централног Балкана. Коришћењем нових резултата истраживања овог култа, проблематизују се питања његовог ширења, разлога за врхунац заступљености у периоду династије Севера, повезаност са рудничким територијама и напослетку нестанка култа. Прилогом се скреће пажња на специфично друштвено-политичко значење култа Јупитера Долихена, које може да објасни нагли раст популарности, али и потоњи пад и потпуни престанак поштовања овог бога.

Кључне речи: култ Јупитера Долихена, централни Балкан, период Севера, рудничке територије, светилиште у Брзој Паланци.

Сведочанства о култу Јупитера Долихена на простору централног Балкана до сада су обрађивана неколико пута. Прва синтеза епиграфског и археолошког материјала била је део студије Љубице Зотовић о такозваним источњачким култовима на територији Горње Мезије. ${ }^{1}$ Након ове пионирске публикације, корпусу грађе (допуњеном са још неколико споменика) вратиле су се Надежда Гавриловић ${ }^{2}$ и Мирослава Мирковић ${ }^{3}$, док се Зеф Мирдита осврнуо на три споменика са територије Дарданије ${ }^{4}$. Наведени радови су пружили тумачења за најважније карактеристике

\footnotetext{
* Текст је настао као фазни резултат рада на пројекту Војвођански простор у контексту европске историје (број 177002) Министарства просвете, науке и технолошког развоја Републике Србије.

${ }^{1}$ Ljubica Zotović, Likovne predstave orijentalnih božanstava na teritoriji Jugoslavije, doktorska disertacija, Filozofski fakultet, Univerzitet u Beogradu 1964, 2-60; Ljubica Zotović, Les cultes orientaux sur le territorie de la Mésie Supérieure, Leiden 1966, 37-55, 85-102.

${ }^{2}$ У, нажалост непубликованој, докторској дисертацији: Nadežda Gavrilović, Kultovi maloazijskih i sirijskih božanstava u rimskim provincijama na centralnom Balkanu, doktorska disertacija, Filozofski fakultet, Beograd 2010, 150-178, 293-310.

${ }^{3}$ Miroslava Mirković, Car i Iuppiter Dolichenus u Gornjoj Meziji, Зборник Матице српске за класичне студије 13, 2011, 123-132.

${ }^{4}$ Zef Mirdita, Prisutnost orijentalnih kultova na području Dardanije, Vjesnik Arheološkog muzeja u Zagrebu 3.s. XXXIV, 2001, 41-44.
} 
овог култа, поставили темеље за његово даље проучавање и отворили питања којима се обраћам овим прилогом.

Иако је општеприхваћено да је култ Јупитера Долихена био снажно везан за припаднике римске војске, и да су они имали примарно место у његовом ширењу диљем западног дела Римског царства, сам начин преношења, односно разлог за његову популарност унутар овог социјалног слоја, није у потпуности јасан. Основна претпоставка следи линију источњачког (сиријског) порекла војника који су поштовали Долихена, или тезу о војним јединицама које су боравком на римском Истоку упознале доктрину култа, прихватиле га и по повратку пренеле на запад. Осим војске, као главни поштоваоци и „промотери“ култа Јупитера Долихена претпостављани су сиријски трговци и источњачки досељеници којима су приписане велика просторна мобилност и активна социјална улога у градовима западног дела Царства. Претресајући постојећа мишљења о ширењу култа Долихена, Ана Колар је недавно указала да претпоставке о улози војника источњачког порекла и јединица које су боравиле на Истоку не могу да објасне механизме прихватања култа, нити његову популарност у оквиру војске. По њеном мишљењу, сиријско порекло дедиканата унутар епиграфског корпуса везаног за Долихенов култ представља исувише мали број случајева који не подржава претпоставку о њиховој пресудној улози у ширењу култа. Слично томе, расположиви подаци не указују на чврсту повезаност војних јединица са запада и простора Долихе, што поткопава аргументацију о масовном прихватању овог божанства од стране војника приликом њихових боравака на поменутом простору. Такође, минимални број сиријских трговаца у дедикацијама Долихену не дозвољава прихватање спекулације о њиховом јаком утицају у промоцији и ширењу поштовања божанства, док учешће ових појединаца у култу може да се објаснити контактима са војском коју су остваривали преко улоге снабдевача. ${ }^{5}$ Уместо постојећих објашњења, А. Колар предлаже промену сета питања о начину ширења култа, преусмеравањем фокуса од наводне привлачности садржине његове теологије ка социјалним мрежама којима су били повезани његови поштоваоци. А. Колар износи интересантан предлог да ширење култа није зависило од његове природе и садржаја, већ од друштвених повезаности следбеника преко којих је тај процес могао да се спроведе. На основу анализе епиграфских споменика она предлаже специфични начин распростирања култа путем међусобне повезаности официра римске војске који су, употребом интензивних комуникацијских канала својствених војсци, лако могли да утичу на ширење ове религије њеним преношењем дуж хоризонталне (у хијерархијском смислу) социјалне линије. Јупитер Долихен је био прихваћен од слоја слично рангираних војних официра, као део официрске супкултуре, „религијске моде“ и један од знакова диференцијације овог слоја војске у односу на друге. Уобичајеним мрежама повезаности које су постојале између официра различитих јединица, на релативно великим међусобним растојањима, култ се за

\footnotetext{
${ }^{5}$ Anna Collar, Military Networks and the Cult of Jupiter Dolichenus, Asia Minor Studien Band 64, Von Kummuh nach Telouch, Historische und archäologische Untersuchungen in Kommagene, Dolicher und Kommagenische Forschungen IV (hrsg. E. Winter), Dr. Rudolf Habelt GMBH, Bonn 2011, 221-226.
} 
кратко време проширио на великом простору. Утицајем који су виши чинови имали на своје подређене, култ се преносио даље по вертикалној хијерархијској оси, што је допринело постепеном укључивању све већег броја војника и резултирало повећањем његове популарности у другој половини II века. ${ }^{6}$ Иста анализа расположиве епиграфске грађе показала је да цивили јесу били укључени у поштовање Јупитера Долихена, али су ови случајеви највећим делом непосредно или посредно били везани за војне контексте, што је А. Колар поново навело на закључак да су присуство војске и њена интензивна комуникација са цивилима били кључни предуслови за ширење култа међу овом категоријом становништва. Епиграфска сведочанства такође су указала да се свештеници познати са натписа, у мање од половине случајева, могу довести у везу са простором Сирије или уопштено Истока, што наводи на претпоставку да је служба свештеника на неки начин, бар делимично, била повезана са пореклом појединаца који су је вршили и, могуће, неком врстом специјализације за ову позицију. ${ }^{7}$

Михаел Блемер, у најновијој синтези о култу Јупитера Долихена, освеженој резултатима истраживања храма у Долихе (данас Дулук Баба Тепеси у Турској), прихвата овакво виђење ширења култа као тренутно најадекватнији начин за објашњење феномена. Он такође указује да је култ Јупитера Долихена био ограниченог значаја у Комагени и Сирији све до формирања комагенске коине у периоду након Веспазијана, те да је његов регионални значај порастао тек у периоду II века, до када није имао никакву посебну улогу у религијском животу поменутог простора. Блемер скреће пажњу да је распростирање култа на римском истоку уследило након екстензивнијег распоређивања трупа на источној граници, па је Јупитер Долихен на овом простору „реимпортован“ када је већ стекао позицују општезначајног култа у Римском царству. Непостојање великог броја посведочених припадника комагенске и сиријске дијаспоре на Западу такође имплицира да за популарност култа нису били пресудни утицаји имиграната који су „у једном даху“, насељавањем западних провинција, успели да испромовишу култ и тако га начине општеприсутним елементом римске религије. Напротив, Блемер указује да је култ Јупитера Долихена био привлачан досељеницима са Истока зато што је могао да служи као адекватна замена за читав низ локалних божанстава ових популација, односно да су различите категорије досељеника са Истока препознавале Јупитера Долихена као божанство које је имало најсличније карактеристике различитим отаџбинским боговима којих није било на Западу. Најзад, Блемер је претпоставио да је постојала свест о храму у Долихе као тачки од опште важности за поштоваоце Јупитера Долихена, али је истакао да тренутно не постоје докази који би недвосмислено указивали да је ово светилиште имало статус центра читавог култа и свих његових заједница. Са друге стране, могуће је спекулисати о извесном степену организације међу свештенством Јупитера Долихена, али свакако не у мери

\footnotetext{
${ }^{6}$ A. Collar, Military Networks, 226-232.

${ }^{7}$ Ibidem, 241-243.
} 
својственој јудаизму и хришћанству. ${ }^{8}$

Ове две интерпретације имају неколико веома важних предности у односу на постојеће. Пре свега, оне као главни разлог ширења култа Јупитера Долихена не виде привлачност његове доктрине, већ специфичан друштвени контекст и мреже повезаности које су прожимале Римско царство. Оваква интерпретација се уклапа у актуална објашњења процеса стварања и функционисања римске државе као „глобалне“ мреже у чијим су оквирима различите надрегионалне друштвене повезаности имале пресудну улогу за одржавање читавог система. ${ }^{9}$ Тумачења А. Колар и М. Блемера такође узимају у обзир динамичан карактер друштвених процеса у Римском царству, у смислу да су одређене друштвене појаве настајале комбинацијом више различитих утицаја под одређеним друштвеним околностима и да су се мењале у зависности од географских, хронолошких и социјалних контекста. ${ }^{10}$ Сходно томе, култ Јупитера Долихена није схваћен као творевина чији је оригиналан и дефинитиван облик настао у Сирији и као такав (непромењен) доспео на Запад, где је због привлачне унутрашње снаге своје доктрине доживео експлозивну популарност. Напротив, култ је био дефинисан под утицајем више чинилаца и играо је важну улогу за неколико различитих (али испреплетаних) друштвених категорија, које су могле, свака из своје перспективе, да га схватају на различите начине и приступају му из међусобно различитих побуда. Напослетку, ова тумачења успела су да превазиђу и уврежено становиште да је источњачка дијаспора била главни носилац култа, и да је његово ширење Римским царством резултат присуства досељеника са Истока. Отварање могућности да је популарност култа била повезана са његовим социјалним значајем унутар војске, упозорава да поштовање „источњачких“ религија није морало да буде условљено етничким или културним припадностима, нити да је подразумевало искључивост на основу ових критеријума. ${ }^{11}$ Једина потешкоћа у овим погледима тиче се нејасноћа на који начин је култ Јупитера Долихена иницијално ушао у фокус припадника римске војске и шта је све утицало на његово друштвено распростирање у самим почецима прихватања овог божанства.

У сваком случају, подаци са простора централног Балкана не супротстављају се изнетом моделу тумачења. Повезаност са војним контекстом је више него јасна и до сада у неколико прилика истицана. Иако епиграфска сведочанства не указаују директно да су поштоваоци Јупитера из Долихе већим делом били војници, контексти налаза споменика и других предмета везаних за култ

\footnotetext{
${ }^{8}$ Michael Blömer, Iuppiter Dolichenus zwischen lokalem Kult und reichsweiter Verehrung, Iuppiter Dolichenus Lokalkult und Reichsreligion im Vergleich (hrsg. M. Blömer und E. Winter), Tübingen 2012, 40, 43, 50-52, 55, $57,59-62,64-65$.

9 Упор. Greg Woolf, Becoming Roman: The Origins of Provincial Civilization in Gaul, Cambridge 1998; Richard Hingley, Globalizing Roman Culture: Unity, Diversity and Empire, Cambridge 2005; Martin Pitts, Globalizing the local in Roman Britain: An anthropological approach to social change, Journal of Anthropological Archaeology 27/4, 2008, 493-506.

${ }^{10}$ Упор. Jane Webster, Creolizing the Roman provinces, American Journal of Archaeology 105, 2001, 209-225.

${ }^{11}$ О сличним закључцима у вези са култом Кибеле и Атиса упор.: Lynn E. Roller, In Search of God the Mother: The Cult of Anatolian Cybele, Berkeley - Los Angeles - London 1999.
} 
недвосмислено упућују на овај закључак. ${ }^{12}$ Уочљива правилност међу епиграфским и археолошким налазима са простора централног Балкана је њихова хронолошка ограниченост на период владавине династије Севера. Тако је 6 од 23 споменика сигурно везано за време династије Севера, док је у 10 случајева извршено оквирно датовање у крај II и прву половину III века. ${ }^{13}$ Повезаност династије Севера и култа Јупитера Долихена добро је позната и претпоставља се да је за време ове династије култ уживао одређену привилеговану позицију и поред тога што није био признат као званична државна религија. ${ }^{14}$ Директна или индиректна подршка Севера обично се објашњава наклоношћу ове династије према Сиријцима што је, како се верује, било условљено сиријским пореклом припадница династије и њиховим утицајем на политику царева ове куће. ${ }^{15}$ Иако се ово објашњење не може у потпуности искључити, сматрам да је разлог за интересовање и заступљеност култа Јупитера Долихена за време ове владарске породице могуће тражити и у другим околностима, које су у складу са новим интерпретацијама ширења култа. Септимије Север је свој долазак на престо првенствено дуговао трупама са простора дунавског лимеса које су га прогласиле императором у Карнунтуму, ${ }^{16}$ где се налазио као намесник провинције Горње Паноније. Претпостављено је да су Септимијеве активности пре самог чина проглашења за цара биле усмерене ка ширењу сопственог утицаја повезивањем са клијентелским мрежама широм Царства у намери да обезбеди подршку за долазак на власт. ${ }^{17}$ Како је остваривање Септимијевих амбиција у потпуности зависило од оданости подунавских и рајнских трупа, постоји могућност да је његова (претпостављена) наклоност култу Јупитера Долихена била део политике што јачег повезивања са војском, односно мрежом официра који су јој

\footnotetext{
${ }^{12}$ Lj. Zotović, Les cultes, 51-52; N. Gavrilović, Kultovi, 174; M. Mirković, Car.

${ }^{13} \mathrm{Lj}$. Zotović, Likovne predstave orijentalnih božanstava, 2-28; Lj. Zotović, Les cultes, 85-102; N. Gavrilović, Kultovi, 293-302; M. Mirković, Car, 125-128. Осим 17 споменика из Горње Мезије у расправу сам укључио и 6 пронађених на подручју југоисточног дела Доње Паноније.

${ }^{14} \mathrm{Lj}$. Zotović, Les cultes, 48-49; Љубица Зотовић, Историјски услови развоја оријенталних култова у римским провиниијама на територији Југославије, Старинар н.c. XIX/1968, 1969, 67; Ljubica Zotović, Der Paganismus in Viminacium, Старинар н.c. XLVII, 1996, 134; Andreas Mócsy, Pannonia and Upper Moesia, a history of the middle Danube provinces of the Roman empire, London - Boston 1974, 256; István Tóth, Destruction of the sanctuaries of Iupiter Dolichenus at the Rhine and in the Danube region (235-238), Acta Archeologica Academiae Scientarie Hungaricae XXV, 1973 fasciculi 1-2, 1973, 114; Monika Hörig, Iupiter Dolichenus, Aufstieg und Niedergang der Römischer Welt 17. 4, Walter de Gruyter, Berlin 1984, 2164. С друге стране постоје и мишљења да се јавно пропагирање култа Јупитера Долихена од стране династије Севера лако може одбацити и да почива на погрешним претпоставкама: Michael P. Speidel, The religion of Iuppiter Dolichenus in the Roman Army, Leiden 1978, 65-66. Опредељујем се за могућност да је овај култ ипак на неки начин био посебно повезан са династијом Севера, без обзира што није морало да буде реч о јавној промоцији или директном наметању Јупитера Долихена као привилегованог божанства било унутар војске било цивилног становништва. Како сам M. P. Speidel, The religion, 66 указује, „власт је пре пратила религијски развој него је водила“, што управо може да објасни интеракцију између куће Севера и култа Јупитера Долихена (вид. ниже).

${ }^{15}$ Lj. Zotović, Les cultes, 48-49; Љ. Зотовић, Историјски услови, 67; M. Mirković, Car, 124, 128-131.

${ }^{16}$ Карнунтум је иначе потврђен као један од најзначајнијих интеррегионалних центара из којег се ширио култ Јупитера Долихена: A. Collar, Military Networks, 241.

${ }^{17}$ Pat Southern, The Roman Empire from Severus to Constantine, London - New York 2001, 28-30; Anthony R. Birley, Septimius Severus: the African Emperor, London - New York 2002, 97.
} 
командовали. Приближавање и благонаклони однос (будућег) цара према култу који је уживао популарност међу официрским делом војске могли су да имају функцију симболичког наглашавања остварене блискости, односно искоришћавања значаја култа (у смислу мреже која је око њега постојала) зарад чвршћег придобијања слоја официра. ${ }^{18}$ У случају да култ Јупитера Долихена схватимо као „религијску моду“ својствену официрској супкултури, појачано интересовање Септимија могло би да се окарактерише као прихватање те моде срачунато са стицањем додатних симпатија у војним круговима дунавско-рајнског лимеса. ${ }^{19}$ Оваква политика је остала на снази и након придобијања власти, чиме је постојећи тренд могао да добије додатни подстрек, будући да је успостављена веза (цара и култа) резултирала ефектом повратне спреге у смислу даљег ширења његове популарности међу војском, администрацијом и делом цивилног становништва, уз појачано јавно исказивање припадности култу. ${ }^{20}$ Пошто се читава владавина С. Севера, као и његових наследника, ${ }^{21}$ првенствено темељила на подршци војске, не изненађује зашто је култ Јупитера Долихена доживео процват управо у периоду прве три деценије III в., нарочито унутар провинција са јаким војним присуством.

У овом светлу може да се објасни и број дедикација упућених Јупитеру Долихену на централном Балкану у време Севера, од којих неки директно позивају и за здравље цара и његове породице. Повећани број посвета Долихену значио би да је интересовање за овај култ било узроковано његовим друштвеним значајем за време династије Севера, пре него појачаним занимањем за источњачка религијска учења. ${ }^{22}$ Тако су дедиканти, истицањем своје припадности религији за коју је постојало империјално интересовање, одашиљали поруку повезаности са важним и моћним друштвеним мрежама које су сезале до највећег ауторитета у Царству. Ова могућност објашњава и појаву споменика које су посвећивали различити слојеви провинцијског друштва на централном Балкану, од намесника провинције, преко припадника војске и градских декуриона до царских робова. Свима њима било је заједничко деловање под царским ауторитетом, те је комуницирање повезаности са култом Јупитера Долихена могло да представља пригодан начин за одавање почасти царској личности/династији као његовом покровитељу, ${ }^{23}$ и уједно подвуче да су

\footnotetext{
${ }^{18}$ Према томе, Септимије Север је могао да буде повезан са култом Јупитера Долихена и пре одласка у Сирију, за који се верује да је битно утицао на интересовање суверена за ово божанство и његово даље ширење у Царству: Lj. Zotović, Les cultes, 48-49; Љ. Зотовић, Историјски услови, 67. Није искључено да је прве контакте са култом Јупитера Долихена Септимије имао за време свог службовања у Сирији у својству легата IV скитске легије али је, имајући у виду политички и војни потенцијал поштоваоца Јупитера Долихена и тренутак када је њихова улога била кључна за Септимијеве планове, вероватније да се приближавање култу догодило у Панонији.

${ }^{19}$ Што је област у којој је Јупитер Долихен уживао највећу популарност и распрострањеност, A. Collar, Military Networks, 236.

${ }^{20}$ Повезаност цара и култа Јупитера Долихена као подстрек за његово даље ширење вид. и Љ. Зотовић, Историјски услови, 67.

${ }^{21}$ Pat Southern, The Roman Empire, 37, 39-40.

${ }^{22}$ Друштвено-политичке пре него религијске мотиве за поштовање Долихена вид. и Z. Mirdita, Prisutnost orijentalnih kultova, 43.

${ }^{23}$ M. Mirković, Car, 130-131 указује да су посвете из периода Севера представљале вид оданости
} 
дедиканти били привилеговани припадношћу утицајном друштвено-религијском кругу. Додатни подстрек исказивању поштовања Јупитеру Долихену могао је да настане услед боравка Септимија Севера, Каракале и Јулије Домне у овим крајевима, ${ }^{24}$ што је био повод за вршење јавне самопромоције појединаца у светлу припадности култу који је уживао наклоност царске фамилије. У том смислу, већина споменика подигнута у време Севера заиста не значи увођење култа у том периоду, ${ }^{25}$ већ његову већу видљивост услед специфичних политичких дешавања и пригодних прилика да се оваква врста припадности истакне.

Повезаност царске династије (Севера) са култом Јупитера Долихена такође може да објасни присуство овог култа на рудничким територијама. Иако су С. Душанић и В. Петровић претпоставили да је Јупитер Долихен својом доктрином на неки начин био повезан са рударством, ${ }^{26}$ то не мора да буде случај. Наиме, формула која је послужила као основа за ову претпоставку, а која је позната на основу три епиграфска сведочанства, говори о пореклу Јупитера Долихена из земље у којој извире гвожђе. Пошто у непосредној и широј околини Долихе нису посведочене рудничке активности ни у римском периоду ни раније, велико је питање да ли је ова карактеризација божанства повезана са подручјем одакле је култ потекао, или је реч о стварању мита (о „земљи извирућег гвожђа“) који није имао директне везе са простором Комагене и Сирије. Другим речима, овај митолошки наратив могао је да настане унутар кругова сиријске/оријенталне дијаспоре у западним провинцијама услед позивања/измишљања традиције чији корени за сада остају непознати и која није морала да има реалне везе са лежиштима и експлоатацијом гвожђа. ${ }^{27}$ Дакле, објашњење присуства култа Јупитера Долихена на рудничким територијама, где су неке од посвета можда потекле од појединаца повезаних са експлоатацијом руде, лежи у нешто другачијој околности. Пошто је систем експлоатације руда био непосредно повезан са царском влашћу која је уживала ексклузивно право/монопол на коришћење металних руда, администрација која се старала о рудничким пословима налазила се под непосредним ауторитетом суверена. ${ }^{28}$ Два главна ослонца читаве рудничке администрације били су царски чиновници и војска, у чијим рукама су се налазиле управљачке полуге на царским рудничким доменима, и који су били повезани са администрацијом и околних домена и провинције (или више њих). Читав систем експлоатације рудних богатстава показује карактеристике добро повезане мреже више друштвених чинилаца који су деловали под окриљем

\footnotetext{
новоустановљеној династији која је побуном дошла на власт.

${ }^{24}$ Lj. Zotović, Les cultes, 48-49; Љ. Зотовић, Историјски услови, 67.

${ }^{25}$ Што образлаже M. Mirković, Car.

${ }^{26}$ Slobodan Dušanić, The Miners ' Cults in Illyricum, Pallas 50, 1999, 134; Vladimir Petrović, Sacerdos of Jupiter Dolichenus from an inscription recently discovered in the vicinity of Viminacium, Старинар 53-54/2003-2004, 2004, 218.

${ }^{27}$ M. Blömer, Iuppiter Dolichenus, 48-50.

${ }^{28}$ Слободан Душанић, Организација римског рударства у Норику, Панонији, Далмацији и Горњој Мезији, Историјски гласник 1-2, 1980, 7-55; Slobodan Dušanić, Roman Mining in Illyricum: Historical Aspects, Dall' Adriatico al Danubio, L'Illirico nell' età greca e romana. Atti del convegno internazionale Cividale del Friuli 2527 settembre 2003 (c. G. Urso), Fondazione Niccolò Canussio, Pisa 2003, 247-270; Alfred Michael Hirt, Imperial Mines and Quarries in the Roman World: Organizational Aspects 27 bc -ad 235, Oxford 2010.
} 
непосредне царске власти, што може да објасни присуство култа Јупитера Долихена на рудничким територијама. Имајући у виду да је за време Севера указивање поштовања Долихену и исказивање припадности његовој заједници достигло врхунац, поготову међу војском и чиновничким апаратом, не изненађује чињеница да се појединачне посвете богу проналазе и у областима у којима је вршена експлоатација минералних лежишта. Исказивање оданости цару и царској породици била је уобичајена пракса у контекстима који су били непосредно везани за његов ауторитет, па посвете у рудничким областима упућене Долихену у периоду династије Севера пре указују на присуство култа због друштвеног статуса (унутар кругова војске/администрације) и наклоњености владара коју је уживао, него на суштинску повезаност његове доктрине са рудничким активностима и животом. Додатно, у случају да се претпоставке о плански насељеним популацијама са Истока на рудничким територијама Балкана узму као оправдане ${ }^{29}$ то би даље могло да објасни појаву култа унутар њихових граница.

Период династије Севера, који је карактеристичан по врхунцу заступљености података о поштовању Јупитера Долихена, праћен је оштрим падом епиграфских и археолошких сведочанстава о култу, што индицира губитак популарности а затим и његов потпуни нестанак. Анализирајући историјске податке и археолошку грађу са подручја рајнско-дунавских провинција, Иштван Тот је закључио да је могуће спекулисати о насилном крају 12 светилишта посвећених Јупитеру из Долихе, који је повезан са турбулентним дешавањима након свргавања последњег владара династије Севера и доласка на власт Максимина Трачанина (235238. г.). Према овом мишљењу, нови цар је посегао за конфискацијом имовине малобројног али имућног слоја сиријских досељеника, али и храмова бога који је био директно повезан са њима. Претпостављајући да су светилишта посвећена Долихену поседовала ризнице богате новцем и предметима од племенитих метала, Тот је предложио да се хоризонти деструкције и оставе вредних предмета у околинама светилишта могу сагледавати у светлу насилних активности и пљачке, које је инструисао Максимин са намером да стекне преко потребна финансијска средства. Тотова претпоставка подразумева да је слој досељеника из Сирије уживао друштвену повлашћеност за време Севера што је, у комбинацији са његовом добростојећом имовинском позицијом, изазвало незадовољство осиромашеног становништва провинција рајнско-дунавског лимеса и резултирало нетрпељивошћу према сиријској дијаспори. Искористивши општу нетрпељивост, Максимин је инспирисао насилну реакцију срачунату са материјалном и политичком добити, која се завршила истискивањем или маргинализацијом Сиријаца и стављањем тачке на култ који је међу њима уживао велику популарност. ${ }^{30}$ Иако је Тотово мишљење општеприхваћено и археолошки трагови заиста указују на мање-више истовремени насилан прекид живота великог броја светилишта на територији која је била под

\footnotetext{
${ }^{29}$ Слободан Душанић, Нови Антинојев натпис и metalla municipii Dardanorum, Жива антика 21 /1, 1971, 241-261; S. Dušanić, The Miners' Cults, 136.

${ }^{30}$ I. Tóth, Destruction of the sanctuaries.
} 
влашћу Максимина Трачанина, ${ }^{31}$ постоје извесни проблеми у оваквој интерпретацији. Пре свега, ово тумачење је исувише уско фокусирано на етничку нетрпељивост и претпоставља готово искључиву повезаност сиријских досељеника са култом Јупитера Долихена, што није случај. Упркос томе што је су етничке или културне стереотипизације могле да доведу до тензија, доживе екстремизацију и резултирају жељом за одмаздом и разрачунавањем са етничким, друштвеним или религијским „другим“ (тј. оријенталном дијаспором), ${ }^{32}$ па су као такве могле да послуже за политичко оправдање активности чији је циљ био учвршћивање позиција новог владара, потребно је имати у виду да култ Јупитера Долихена није био структуриран искључиво по етничкој логици, већ је представљао и врсту статусног и „еснафског“ социјалног тренда. Ако прихватимо да су најистакнутији поштоваоци култа били официри средњег или вишег ранга унутар војске, да је њихова међусобна повезаност и припадност истој супкултури била и заслужна за ширење култа, и да је династија Севера у извесној мери била директно везана за ове мреже (и уједно култ Јупитера Долихена), не треба одбацити могућност да је насилан крај култа био (бар донекле) повезан и са сукобом фракција унутар саме војске (и администрације) на територији под непосредном контролом Максимина Трачанина. Напад на религијско-друштвену заједницу Долихена могао је да има за циљ и обрачун са делом војске/официра која је била схватана као просеверијанска и потенцијално опасна по власт новог цара. Чак и у случају да се ови догађаји нису одигравали непосредно по убиству Александра Севера, краткотрајна Максиминова владавина била је испуњена сукобима са различитим завереницима, неистомишљеницима и на крају Сенатом, ${ }^{33}$ па је повод за обрачун са политичким опонентима могао да настане у различитим тренуцима током ове три изразито нестабилне године. Култ Јупитера Долихена, у очима Максиминове владе, могао је да представља оличење опасних завереничких мрежа у круговима војске и администрације, повезаних и са категоријама становништва које нису подржавале његову власт (сиријска дијаспора), те је насилна реакција према храмовима циљала на уништавање тачака око којих се

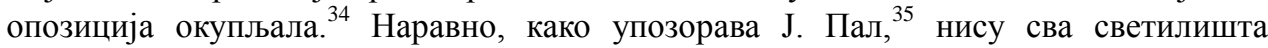

\footnotetext{
${ }^{31}$ M. P. Speidel, The religion, 72-73; M. Hörig, Iupiter Dolichenus, 2173. Joachim Pahl, Der Kult des Jupiter Dolichenus, Ausbreitung, Selbstverständnis, Niedergang, auf der Basis statistischer Erhebungen und mit einem ergänzenden Corpus, Dissertation, Westfälischen Wilhelms-Universität, Münster 2010, 318-332, 338-340, указује да нису сви Долихенови храмови страдали у Максиминовим нападима. Он сматра да су на удару била светилишта везана за приватну сферу и неримско порекло следбеника култа, док су храмови који су били јаче повезани са званичном сфером и култном заједницом сачињеном од појединаца римског порекла били поштеђени. Пал указује и да је близина појединачних храмова средишту Максиминове власти такође утицала да ли ће или неће бити нападнути.

${ }^{32}$ Стереотипизиране ставове и виђења популација са Истока из перспективе Римљана доноси Веnјаmin Isaac, The Invention of Racism in Classical Antiquity, Princeton - Oxford 2004, 304-351.

${ }^{33}$ Pat Southern, The Roman Empire, 64-67.

${ }^{34}$ Иако је уништавање храмова Јупитера Долихена на подручју рајнских и дунавских провинција задало одлучујући ударац култу на овом простору, ови догађаји нису утицали да он у потпуности нестане у читавом Царству. Неколико других околоности, као што је уништење храма у самој Долихе 253.г. и општа друштвена, политичка и економска криза, задали су последње ударце овом култу. Унутрашњи сукоби и фрагментација територије Царства под различитим претендентима утицали су на сламање устаљених канала комуникације међу официрима и смањење опште мобилности, што је допринело постепеном
} 
морала да страдају у овим сукобима, али је несумњиво да су Максиминове акције као исход имале одлучујући ударац на друштвене мреже и кругове који су постојали око култа Долихена, бар на подручју дунавских и рајнских провинција.

Насилан прекид постојања неких од храмова Јупитера Долихена непосредно је повезан са остацима светилишта у Брзој Паланци. ${ }^{36}$ Овај локалитет је уврштен у Тотову листу разорених светилишта на основу велике фрагментације култног мобилијара који је пронађен унутар објекта, и калцификације на статуама која је узета као показатељ контакта са ватром. ${ }^{37}$ Објекат у којем су пронађени многобројни предмети везани за култ Јупитера Долихена је протумачен као светилиште (sacrarium) које је било у вези са оближњим утврђењем и I кохортом Крићана, чија је дедикација и пронађена на локалитету. Љ. Зотовић и Н. Гавриловић указале су да је површина коју је захватала грађевина у Брзој исувише мала да би могла да се сматра светилиштем у правом смислу речи и приклониле се становишту да је реч о капели за чување култних предмета, или за (наводну) осаму Долихенових свештеника. ${ }^{38}$ Иако на први поглед изгледа оправдано претпоставити да је зграда пронађена у Егети на неки начин имала култне сврхе, макар и у сведеном обиму, постоји могућност да је објекат био искоришћен за склањање култних предмета из храма који се налазио на неком другом месту. Мала површина простора која готово у потпуности онемогућава било какво кретање, датовање читаве целине у период након владавине Елиогабала, велика фрагментација статуа од којих су у појединим случајевима у питању мали делови који не припадају ниједној од боље очуваних скулптура, ${ }^{39}$ могућност да су статуе биле изложене ватри иако приликом ископавања нису констатовани трагови пожара, као и разлика квалитета скулптура у односу на скромну технику зидања објекта ${ }^{40}$ допуштају и овакво тумачење. Уз ове околности можда је од значаја да приликом ископавања нису пронађени предмети од сребра и злата (са изузетком једног денара), док је рог бика на једној од скулптура, који је био направљен од сребрног лима, недостајао. ${ }^{41}$ Да је пронађени инвентар донет са неког

напуштању и потпуном гашењу заједница Јупитера Долихена. Непостојање чврсте и централизоване организације унутар култа, као и ограниченост само на одређене категорије становништва, додатно су допринели губитку његове популарности и потоњем потпуном окончању: А. Collar, Military Networks, 244; M. Blömer, Iuppiter Dolichenus, 77; J. Pahl, Der Kult des Jupiter Dolichenus, 341-342; M. P. Speidel, The religion, 73-75; M. Hörig, Iupiter Dolichenus, 2174.

${ }^{35}$ Вид. напомену 31.

36 Душанка Вучковић-Тодоровић, Светилиште Јупитера Долихена у Брзој Паланци, Старинар н.с. XV/XVI 1964-1965, 1966, 173-182; Lj. Zotović, Les cultes, 87-96.

${ }^{37}$ I. Tóth, Destruction of the sanctuaries, 111.

${ }^{38}$ Lj. Zotović, Les cultes, 88; N. Gavrilović, Kultovi maloazijskih i sirijskih božanstava, 177.

39 Д. Вучковић-Тодоровић, Светилиште Јупитера Долихена, 176; Lj. Zotović, Likovne predstave orijentalnih božanstava, 9-10.

${ }^{40}$ Оштећења код најбоље сачуваних статуа везана су или за предео главе или читаве фигуре бога, што може да индицира уништавање усмерено ка негацији лика божанства. Пошто ископавањима нису пронађени делови који недостају, постоји могућност да се они оригинално и нису налазили унутар грађевине. M. Mirković, Car, 125-126 такође износи мишљење о намерном уништавању статуа, али као разлог види брисање успомене на Елагабала јер претпоставља да се лик овог цара налазио на неким од скулптура.

${ }^{41}$ Из неког разлога на једној од представа бика на месту левог рога се налазио гвоздени клин на којем су 
другог места упозорава и једна од представа, која је била намењена за нишу и са задње стране имала остатке малтера којим је била учвршћена за удубљење у свом оригиналном окружењу. ${ }^{42}$ Иако су наведени показатељи далеко од сигурних, узимајући у обзир дешавања за време Максимина Трачанина, ${ }^{43}$ не може се одбацити вероватноћа да су пронађени предмети склоњени после хипотетичког напада на храм Јупитера Долихена који се налазио на некој другој локацији у Егети. Измештање култних предмета могло је да има за циљ чекање бољих времена за поштоваоце култа, која се никада нису догодила, па је мобилијар остао у свом склоништу до откривања у XX веку. Како год да тумачимо налаз из Брзе, остаје чињеница да на простору централног Балкана за сада нису познати споменици Јупитера Долихена млађи од периода средине III в., што указује да је судбина култа и на овом подручју била повезана са ширим дешавањима на дунавско-рајнском лимесу.

\section{Извори и литература:}

Arsenijević, Mirjana, Skupni nalazi rimskog novca II i III veka u Gornjoj Meziji kao arheološke potvrde varvarskih upada, magistarski rad, Filozofski fakultet, Univerzitet u Beogradu, 2002.

Birley, Anthony R., Septimius Severus: the African Emperor, London - New York 2002.

Blömer, Michael, Iuppiter Dolichenus zwischen lokalem Kult und reichsweiter Verehrung, Iuppiter Dolichenus Lokalkult und Reichsreligion im Vergleich (hrsg. M. Blömer und E. Winter), Tübingen 2012, 39-92.

Webster, Jane, Creolizing the Roman provinces, American Journal of Archaeology 105, 2001, 209 225.

Woolf, Greg, Becoming Roman: The Origins of Provincial Civilization in Gaul, Cambridge 1998.

Вучковић-Тодоровић, Душанка, Светилиште Јупитера Долихена у Брзој Паланци, Старинар н.c. XV-XVI/ 1964-1965, 1966, 173-182.

Gavrilović, Nadežda, Kultovi maloazijskih i sirijskih božanstava u rimskim provincijama na centralnom Balkanu, doktorska disertacija, Filozofski fakultet, Beograd, 2010.

Душанић, Слободан, Нови Антинојев натпис и metalla municipii Dardanorum, Жива антика 21 /1, 1971, 241-261.

Душанић, Слободан, Организаџија римског рударства у Норику, Панонији, Далмащији и

примећени остаци сребрног лима, што би указивало да је лим одстрањен пре формирања слоја: Д. Вучковић-Тодоровић, Светилиште Јупитера Долихена, 175.

${ }^{42} \mathrm{Lj}$. Zotović, Likovne predstave orijentalnih božanstava, 47-48.

43 Нестабилности на мезијском лимесу за време Максимина Трачанина могу се претпоставити и на основу пронађених остава новца. Тако три оставе могу да се вежу за период после Александра Севера, од којих је једна, датована на почетку владавине Максимина Трачанина, пронађена у темељима зграде унутар утврђена у Равни на Дунаву: Mirjana Arsenijević, Skupni nalazi rimskog novca II i III veka u Gornjoj Meziji kao arheološke potvrde varvarskih upada, magistarski rad, Filozofski fakultet, Univerzitet u Beogradu 2002, 23, 25, 27; Владимир Кондић, Налаз денара из утврђења Равна, Нумизматичар 6, 1983, 51-77. 
Горъој Мезији, Историјски гласник 1-2, 1980, 7-55.

Dušanić, Slobodan, The Miners' Cults in Illyricum, Pallas 50, 1999, 129-139.

Dušanić, Slobodan, Roman Mining in Illyricum: Historical Aspects, Dall' Adriatico al Danubio, L'Illirico nell' età greca e romana. Atti del convegno internazionale Cividale del Friuli 2527 settembre 2003 (c. G. Urso), Fondazione Niccolò Canussio, Pisa 2003, 247-270.

Zotović, Ljubica, Likovne predstave orijentalnih božanstava na teritoriji Jugoslavije, doktorska disertacija, Filozofski fakultet, Beograd 1964.

Zotović, Ljubica, Les cultes orientaux sur le territorie de la Mésie Supérieure, Leiden 1966.

Зотовић, Љубица, Историјски услови развоја оријенталних култова у римским провинцијама на територији Југославије, Старинар н.с. XIX/1968, 1969, 59-74.

Zotović, Ljubica, Der Paganismus in Viminacium, Старинар н.c. XLVII, 1996, 127-137.

Isaac, Benjamin, The Invention of Racism in Classical Antiquity, Princeton-Oxford 2004.

Collar, Anna, Military Networks and the Cult of Jupiter Dolichenus, Asia Minor Studien Band 64, Von

Kummuh nach Telouch, Historische und archäologische Untersuchungen in Kommagene, Dolicher und Kommagenische Forschungen IV (hrsg. E. Winter), Dr. Rudolf Habelt GMBH, Bonn 2011, 217-245.

Кондић, Владимир, Налаз денара из утврђења Равна, Нумизматичар 6, 1983, 51-77.

Mirdita, Zef, Prisutnost orijentalnih kultova na području Dardanije, Vjesnik Arheološkog muzeja u Zagrebu 3, s. XXXIV, 2001, 37-58.

Mirković, Miroslava, Car i Iuppiter Dolichenus u Gornjoj Meziji, Зборник Матице српске за класичне студије 13, 2011, 123-132.

Mócsy, Andreas, Pannonia and Upper Moesia, a history of the middle Danube provinces of the Roman empire, London-Boston, 1974.

Pahl, Joachim, Der Kult des Jupiter Dolichenus, Ausbreitung, Selbstverständnis, Niedergang, auf der Basis statistischer Erhebungen und mit einem ergänzenden Corpus, Dissertation, Westfälischen Wilhelms-Universität, Münster, 2010.

Petrović, Vladimir, Sacerdos of Jupiter Dolichenus from an inscription recently discovered in the vicinity of Viminacium, Старинар 53-54/2003-2004, 2004, 217-224.

Pitts, Martin, Globalizing the local in Roman Britain: An anthropological approach to social change, Journal of Anthropological Archaeology 27/4, 2008, 493-506.

Roller, Lynn E., In Search of God the Mother: The Cult of Anatolian Cybele, Berkeley - Los Angeles - London 1999.

Southern, Pat, The Roman Empire from Severus to Constantine, London - New York 2001.

Speidel, Michael P. The religion of Iuppiter Dolichenus in the Roman Army, Leiden 1978.

Tóth, István, Destruction of the sanctuaries of Iupiter Dolichenus at the Rhine and in the Danube region (235-238), Acta Archeologica Academiae Scientarie Hungaricae XXV, 1973 fasciculi 1-2, 1973, 109-116.

Hingley, Richard, Globalizing Roman Culture: Unity, Diversity and Empire, Cambridge 2005.

Hirt, Alfred Michael, Imperial Mines and Quarries in the Roman World: Organizational Aspects 27 bc -ad 235, Oxford 2010.

Hörig, Monika, Iupiter Dolichenus, Aufstieg und Niedergang der Römischer Welt 17. 4, Walter de Gruyter, Berlin 1984, 2137-2176. 


\title{
NOTES ON THE CULT OF JUPITER DOLICHENUS IN THE CENTRAL BALKANS
}

\begin{abstract}
Summary
The paper draw attention to new interpretational frameworks for the spread of the cult of Jupiter Dolichenus which emphasize the role of social networks and connectivity as main reasons for adoption and popularity of the deity, especially among the officers of the Roman army. Using this standpoint the paper has focused on the area of the central Balkans and problematized the questions of increased popularity of the cult in period of the Severi, the appearance of the cult inside mining districts, and the find from Brza Palanka. It has been argued that Septimus Severus has acquainted with the cult aiming to strengthen the connection with the network of the officers of the Danube-Rhine provinces, which has affected the status of the cult in years to come, and additionally increased its popularity among the military and administrative circles. The link between the emperor/dynasty and the cult could have inspired tendencies towards enhanced public communication of the membership to privileged socio-religious network of Dolichenus adherents, which could explain why the majority of dedications in the central Balkans appeared in the period of the Severan dynasty. Similarly, the presence of the cult inside mining districts are not to be explained by intrinsic connection of Dolichenus' doctrine with mining and ore, but by the role that army and imperial bureaucracy, which were the social categories most inclined to the cult, played in the system of ore exploitation. Finally, the find from Brza Palanka (Egeta), interpreted as small chapel that served for the keeping of cult's items, is speculated here to be a place where the surviving objects from the temple (located somewhere else in the area of ancient Egeta) were stored after the violent actions against the cult that took place during the reign of Maximinus Thrax.
\end{abstract}

Keywords: cult of Jupiter Dolichenus, Central Balkans, Severan period, mining territories, sacred sites in Brza Palanka. 